Eur. J. Clin. Chem. Clin. Biochem.

Vol. 30, 1992, pp. 815-822

(C) 1992 Walter de Gruyter \& Co. Berlin · New York

\title{
Calcium Regulating Hormones after Oral and Intravenous Calcium Administration
}

By K. Herfarth ${ }^{1}$, Sabine Drechsler ${ }^{2}, W$. Imhoff $^{2}, M$. Schlander $^{2}, M$. Engelbach $^{3}, A$. Maier $^{3}$ and H. SchmidtGayk $^{3}$

${ }^{1}$ Department of Surgery, Division 2.1, University of Heidelberg

${ }^{2}$ Clinical Research, Sandoz AG, Nuremberg

${ }^{3}$ Endocrine Laboratory, Laboratory Group, Heidelberg

(Received December 28, 1991/August 4, 1992)

Summary: The aim of this study was to determine the changes in serum calcium concentration and in the concentrations of calcium regulating hormones after a single oral or intravenous calcium administration. Standard dosages of calcium, as used in routine patient care, were employed.

Intact parathyrin, calcitonin, calcitriol, calcidiol, total calcium, ionized calcium, total protein and phosphate were determined in 12 healthy young men before and up to $8 \mathrm{~h}$ after oral and intravenous administration of calcium.

During a fortnight there were four study days with $1000 \mathrm{mg}$ calcium orally (p. o.), $2000 \mathrm{mg}$ orally, $180 \mathrm{mg}$ calcium intravenous (i.v.) and a control day without calcium. During the study the men were on a low calcium diet.

We observed a sharp increase in the calcium concentration after i.v. administration $(15 \mathrm{~min}$ : total Ca: $+0.48 \pm 0.32 \mathrm{mmol} / \mathrm{l}$; ionized $\mathrm{Ca}:+0.25 \pm 0.15 \mathrm{mmol} / \mathrm{l} ; \mathrm{p}<0.01)$. The concentration increase after the two oral loads was nearly identical. The maximal concentration of total calcium was reached after $120 \mathrm{~min}$ $(1000 \mathrm{mg}:+0.1 \pm 0.04 \mathrm{mmol} / \mathrm{l} ; \mathrm{p}<0.001 ; 2000 \mathrm{mg}:+0.12 \pm 0.04 \mathrm{mmol} / \mathrm{l} ; \mathrm{p}<0.001)$. There was a significant increase in urinary calcium after all modes of calcium administration.

Calcitonin increased significantly only after i. v. injection of calcium $(+9.2 \pm 3.4 \mathrm{pmol} / \mathrm{l} ; \mathrm{p}<0.001)$ while parathyrin decreased significantly after all modes of calcium administration (i. v.: $15 \mathrm{~min}:-1.9 \pm 0.88 \mathrm{pmol} / \mathrm{l}$; p $<0.01 ; 1000 \mathrm{mg}: 90 \mathrm{~min}:-0.78 \pm 0.75 \mathrm{pmol} / \mathrm{l} ; \mathrm{p}<0.001 ; 2000 \mathrm{mg}: 90 \mathrm{~min}:-1.02 \pm 0.57 \mathrm{pmol} / \mathrm{l}$; $\mathrm{p}<0.001$ ). Almost total suppression of parathyrin secretion occurred at the upper end of the physiological range for serum calcium. There was no statistically relevant change of either calcidiol or calcitriol throughout each study day.

The phosphate concentration showed an earlier increase to a higher afternoon level after all three modes of calcium administration, compared with the control day.

In conclusion, both the oral or intravenous administration of calcium significantly influence the regulation of calcium metabolism. Both oral dosages yielded an increase of serum calcium with depression of parathyrin secretion without major risk of hypercalcaemia. Suppression of intact parathyrin for evaluation of patients with suspected hyperparathyroidism may easily be effected by oral ingestion of $1000 \mathrm{mg}$ calcium. 


\section{Introduction}

Calcium absorption after oral calcium loading has been investigated by various authors $(1-7)$. The results of these studies were controversial with regard to the fraction of intestinal calcium absorption in relation to the calcium load. In some of the studies, a change in fractional absorption after different amounts of calcium was observed $(1,6,7)$, whereas this was not found by Behne et al. (3).

Numerous studies have also been reported on the effects of calcium on parathyroid hormone in vitro and in vivo $(8-22)$ or its interference with other calcium regulating hormones $(2,23)$. Many of these studies showed the sigmoidal relationship between calcium and parathyrin $(9-12,16,18)$.

Intravenous administration of calcium resulted in a strong suppression of the parathyrin secretion rate to $40 \%$ of the mean basal concentration $(14,20)$. Oral calcium administration caused a reduction of parathyrin release by $50 \%(15,21)$ or up to $73 \%(22)$. Parathyrin was often measured only with radioimmunoassays for parathyroid hormone fragments (14, $17,22)$, which are not as sensitive as the sandwichtype assays for the intact hormone $(15,20,21)$. Because of the short half-life of the intact hormone (24, 25 ) its measurement reflects the physiological state of the parathyroid gland more accurately than the determination of parathyroid fragments, whose concentration is considerably influenced by kidney function. To our knowledge, the effect of oral and intravenous administration of calcium in different doses on intact parathyroid hormone and other calcium regulating hormones has not been determined in detail.

Using a sensitive assay for intact parathyrin and measuring all calcium regulating hormones, our aim was to determine the way in which different modes of administration and different dosages affect serum calcium concentrations and calcium regulating hormones, especially the secretion of intact parathyrin. We administered standard calcium preparations of the type often used in routine patient care.

\section{Materials and Methods}

\section{Study subjects}

Twelve healthy men (mean age $26.4 \mathrm{a}$; range $21-45 \mathrm{a}$ ) volunteered for this study, which was approved by the ethics committee of the University of Heidelberg. All subjects were in good physical condition, and no abnormalities in serum calcium, phosphate, alkaline phosphatase, total protein, urea and creatinine were observed. No subject took any other drugs during and at least one week before the study.

\section{Materials}

We used Calcium-Sandoz ${ }^{\circledast}$ fortissimum tablets for oral administration. One tablet contains $1000 \mathrm{mg}$ calcium. The tablets were dissolved in water and ingested. The volunteers took one tablet for the $1000 \mathrm{mg}$ and two tablets for the $2000 \mathrm{mg}$ dose.

For intravenous administration we used Calcium-Sando $z^{\circledR}$ injection solution $20 \%$ containing $180 \mathrm{mg}$ calcium in a $10 \mathrm{ml}$ ampoule.

\section{Study course}

The study was performed within 14 days in each volunteer. It consisted of 4 blood sampling periods with intervals of 2 or 3 days when the volunteers were on a low calcium diet (no milk products) without suffering from calcium hunger (no elevation of intact parathyrin was observed). On the four sampling days they had a low-calcium breakfast at $0800 \mathrm{~h}$ (bread, $15 \mathrm{~g}$ of butter, marmalade: total amount of calcium $<50 \mathrm{mg}$ ) and a low-calcium lunch after the $1300 \mathrm{~h}$ collection (rice and vegetables: total amount of calcium $<100 \mathrm{mg}$ ). Control samples were obtained from each volunteer before the administration of calcium. On the following study days, three different calcium doses (1000 mg p. 0., $2000 \mathrm{mg}$ p. 0. , or $180 \mathrm{mg}$ i. v.) were applied in a randomized order.

An indwelling catheter was placed in a forearm vein at $0845 \mathrm{~h}$ and a blood sample was taken. All subjects received their calcium dose at $0900 \mathrm{~h}$. The calcium tablets were dissolved in water and ingested. The $180 \mathrm{mg}$ calcium gluconate dose was slowly injected within $5 \mathrm{~min}$ through the indwelling catheter. Blood samples were taken every $15 \mathrm{~min}$ in the first hour, every $30 \mathrm{~min}$ in the following two hours, and hourly in the remaining five hours. Each time we sampled about $7 \mathrm{ml}$ EDTA-plasma and closed the catheter with a stylet. Additionally, $10 \mathrm{ml}$ blood were taken before the first sampling after the i. v. administration to clean the indwelling catheter.

The blood samples were centrifuged within $4 \mathrm{~h}$ and stored frozen at $-30^{\circ} \mathrm{C}$ until assayed. For the ionized calcium series, an additional $2 \mathrm{ml}$ of blood were taken in a syringe, and analysed immediately.

Urine was sampled at $0900 \mathrm{~h}$ (spot sample), $1300 \mathrm{~h}$ and $1700 \mathrm{~h}$ (both four hour samples). Before measuring, $\mathrm{HCl}$ was added and the urines were heated to dissolve calcium salts.

\section{Clinical chemical analyses}

Serum calcium and urinary calcium were determined by atomic emission spectrophotometry corrected for sodium interference (CAFM, Eppendorf Gerätebau, Hamburg, Germany). The protein-adjusted calcium concentration was calculated by a formula of Husdan (26).

The ionized calcium and $\mathrm{pH}$ values were determined with an ion selective electrode (Ionized Calcium Analyser ICA 2, Radiometer Copenhagen) immediately after the blood sample had been drawn. The measured ionized calcium value was automatically adjusted to a $\mathrm{pH}$ of 7.4.

Serum phosphate, alkaline phosphatase, total protein, urea, creatinine, sodium, potassium, and urine creatinine were determined with a Hitachi-737 analyser. Reagents were obtained from the Boehringer Mannheim Corporation, Mannheim, Germany.

\section{Calcitonin}

Calcitonin was determined with an immunoradiometric assay (IRMA) similar to the method of Motté et al. (27) (M. Engelbach, in preparation). 


\section{Parathyrin}

Intact parathyrin concentrations were determined in duplicate using a two-site immunoradiometric assay (IRMA). This assay will be described in detail by Herfarth et al. (in preparation). It uses a polyclonal anti-human parathyrin $(1-34)$ antibody raised in a rabbit and a monoclonal anti-human parathyrin (44-68) antibody (Mab 14H5) from Medgenix, Brussels, Belgium (28). This IRMA recognizes only the intact parathyrin molecule and has no cross-reactivity with hormone fragments in the physiological range. The sensitivity of this assay was 0.13 $\mathrm{pmol} / \mathrm{l}$. The intra-assay variation coefficients were below $7.3 \%$ in the normal range. The normal concentrations ranged from 0.8 to $5.3 \mathrm{pmol} / \mathrm{l}$ (mean $2.77 \pm 1.18 \mathrm{pmol} / \mathrm{l}$; median $2.7 \mathrm{pmol} / \mathrm{l}$ ).

\section{Calcitriol}

Calcitriol was determined with a radioimmunoassay after high performance liquid chromatography of serum extracts according to Scharla et al. (29).

\section{Calcidiol}

Calcidiol (25-hydroxycholecalciferol) was determined with a competitive protein-binding assay without chromatography according to Bothe et al. (30).

\section{Statistics}

For statistical analysis Student's t-test for paired samples was employed.

\section{Results}

\section{Total calcium}

A sharp increase in the serum calcium concentration (protein-adjusted) of $0.48 \pm 0.32 \mathrm{mmol} / \mathrm{l}(\mathrm{p}<0.05$; range: $0.28-1.47 \mathrm{mmol} / \mathrm{l}$ ) was observed $15 \mathrm{~min}$ after i.v. administration of $180 \mathrm{mg}$ calcium as calcium gluconate. Calcium decreased quickly but remained at an elevated level for the $480 \mathrm{~min}$ of observation $(\min 480:+0.03 \pm 0.04 \mathrm{mmol} / 1$ (mean $\pm \mathrm{SD})$; $\mathrm{p}<0.01)$.

A smaller increase in serum calcium concentration (protein adjusted) was observed after oral administration. After a $1000 \mathrm{mg}$ calcium load, a statistically significant increase was noted at $30 \mathrm{~min}(+0.05$ $\pm 0.03 \mathrm{mmol} / \mathrm{l} ; \mathrm{p}<0.05)$ and the maximal concentration of serum calcium (protein-adjusted) occurred after $120 \mathrm{~min}(+0.1 \pm 0.04 \mathrm{mmol} / 1 ; \mathrm{p}<0.001$; range: $0.03-0.15 \mathrm{mmol} / \mathrm{l})$. The $2000 \mathrm{mg}$ calcium load also produced a statistically significant increase at $30 \mathrm{~min}$ $(+0.07 \pm 0.05 \mathrm{mmol} / \mathrm{l} ; \mathrm{p}<0.05)$ and a maximal increase after $120 \mathrm{~min}(+0.12 \pm 0.04 \mathrm{mmol} / \mathrm{l}$; $\mathrm{p}<0.001$; range: $0.07-0.17 \mathrm{mmol} / \mathrm{l})$. Both doses resulted in increased serum concentrations until the end of observation $(\min 480: 1000 \mathrm{mg}:+0.03 \pm 0.05$ $\mathrm{mmol} / \mathrm{l} ; \mathrm{p}<0.001 ; 2000 \mathrm{mg}:+0.04 \pm 0.04 \mathrm{mmol} / \mathrm{l}$; $\mathrm{p}<0.001)$. There were no differences between the calcium concentrations of persons receiving $1000 \mathrm{mg}$ at the beginning and those receiving the same dosage at the end of the test period. Similarly, the changes in calcium concentrations after the other modes of application did not differ between the beginning and the end of the test period. The concentrations of total calcium during the four study days are shown in figure 1.

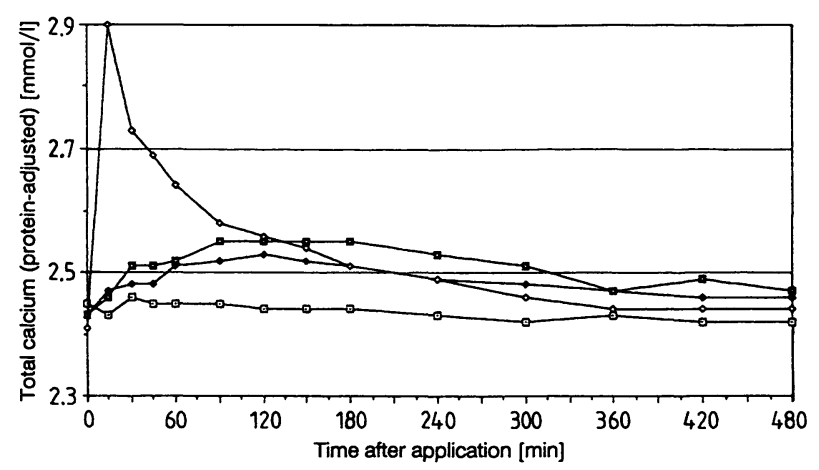

Fig. 1. Total calcium concentrations (protein-adjusted) on the control day and after the three different modes of calcium application. (As the figures seemed overloaded by the introduction of error bars, these were omitted.) Calcium application:

$\begin{array}{cc}-\square-\quad \text { control } \\ -\square- & 1000 \mathrm{mg} \text { oral } \\ -\square- & 2000 \mathrm{mg} \text { oral } \\ -\diamond-\quad 180 \mathrm{mg} \text { i.v. }\end{array}$

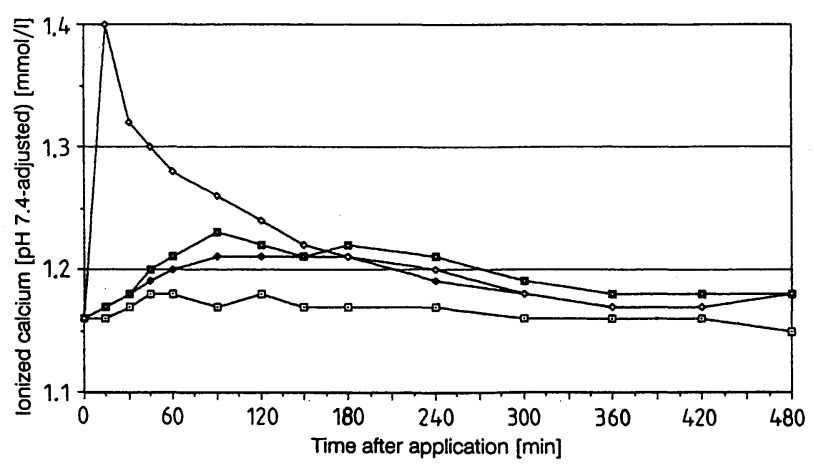

Fig. 2. Ionized calcium concentrations ( $\mathrm{pH} 7.4$ adjusted) on the control day and after the three different modes of calcium application.

Calcium application:

$\begin{array}{cc}-\square- & \text { control } \\ -\checkmark- & 1000 \mathrm{mg} \text { oral } \\ -\square- & 2000 \mathrm{mg} \text { oral } \\ -\diamond-\quad & 180 \mathrm{mg} \text { i.v. }\end{array}$

\section{Ionized calcium (pH-adjusted)}

The ionized calcium determinations ( $\mathrm{pH}$ adjusted) yielded similar results (fig. 2). A sharp increase occurred after i.v. administration with a maximal concentration after $15 \mathrm{~min}(+0.25 \pm 0.15 \mathrm{mmol} / \mathrm{l}$; $\mathrm{p}<0.01$; range $0.15-0.69 \mathrm{mmol} / \mathrm{l})$, and a slight in- 
crease of ionized calcium was found after oral administration with a statistically significant increase at 60 $\min (1000 \mathrm{mg}:+0.04 \pm 0.02 \mathrm{mmol} / \mathrm{l} ; \mathrm{p}<0.05 ; 2000$ mg: $+0.05 \pm 0.04 \mathrm{mmol} / \mathrm{l} ; \mathrm{p}<0.1)$ and a maximal concentration after $120 \mathrm{~min}(1000 \mathrm{mg}:+0.06 \pm 0.02$ $\mathrm{mmol} / \mathrm{l} ; \mathrm{p}<0.01$; range: $0.02-0.12 \mathrm{mmol} / \mathrm{l})$ and 90 $\min (2000 \mathrm{mg}:+0.07 \pm 0.04 \mathrm{mmol} / \mathrm{l} ; \mathrm{p}<0.05$; range: $0.01-0.14 \mathrm{mmol} / \mathrm{l})$. The ionized calcium concentrations remained elevated after all three modes of administration until the end of the observation period ( $\min 480$ : all: $+0.02 \mathrm{mmol} / \mathrm{l} ; \mathrm{p}<0.05$ ).

\section{Urinary excretion}

There was an increase of urinary calcium excretion after all three modes of administration $(1000 \mathrm{mg}$ p. o.: $\mathrm{p}<0.05 ; 2000 \mathrm{mg}$ p. o.: $\mathrm{p}<0.05 ; 180 \mathrm{mg}$ i.v.: $\mathrm{p}<0.001$ ) (fig. 3). A mean calcium concentration of $9.82 \pm 5.11 \mathrm{mmol} / \mathrm{g}$ creatinine $(1.11 \pm 0.58 \mathrm{mmol} /$ mmol creatinine) was observed after the intravenous dosage. This was higher than the excretion after the $1000 \mathrm{mg}(7.57 \pm 3.57 \mathrm{mmol} / \mathrm{g}$ creatinine $(0.86 \pm 0.4$ $\mathrm{mmol} / \mathrm{mmol}$ creatinine $))$ or the $2000 \mathrm{mg}(6.62 \pm 1.31$

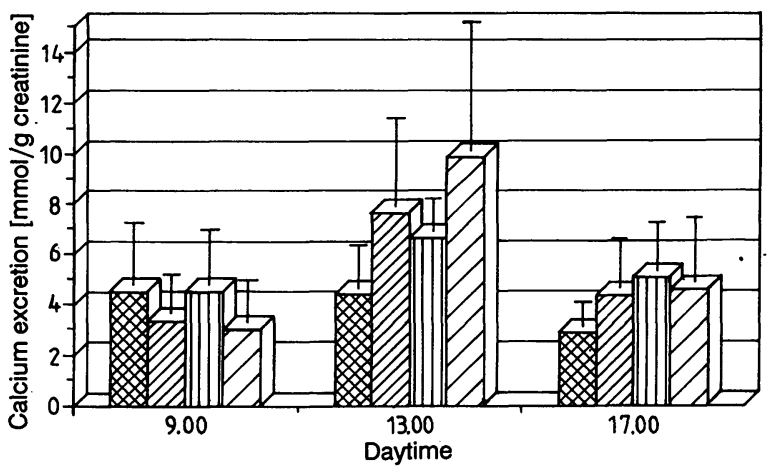

Fig. 3. Urinary calcium excretion on the control day and after the three different modes of calcium application at the different sampling times. The error bars represent the standard error. (Data of 2 indidviduals were not available after the i.v. and the $1000 \mathrm{mg}$ dosage and of 3 individuals after the $2000 \mathrm{mg}$ dosage.)

Calcium application:

control

$1000 \mathrm{mg}$ oral

四 $2000 \mathrm{mg}$ oral

b $180 \mathrm{mg}$ i. v. $\mathrm{mmol} / \mathrm{g}$ creatinine $(0.75 \pm 0.15 \mathrm{mmol} / \mathrm{mmol}$ creatinine)) oral dose, but the difference was not statistically significant. In the late afternoon the urinary calcium excretion rates after all three modes of administration were statistically still significantly higher than on the control day.

Further data on urinary calcium excretion are shown in table 1.

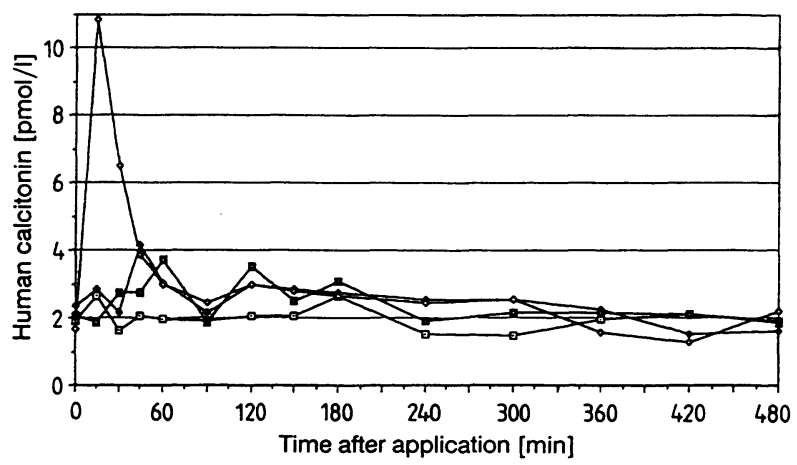

Fig. 4. Calcitonin concentrations on the control day and after the three different modes of calcium application.

Calcium application:

- $\square$ - control

$-1000 \mathrm{mg}$ oral

- $-\quad 2000 \mathrm{mg}$ oral

$-\diamond-180 \mathrm{mg}$ i.v.

\section{Calcitonin}

Calcitonin concentrations increased significantly only after the i.v. administration of calcium (fig. 4). The maximal concentration was found after $15 \mathrm{~min}$ with a difference of $9.2 \pm 3.37 \mathrm{pmol} / \mathrm{l}$ versus the concentration before administration $(\mathrm{p}<0.001$; range: $4.2-$ $13.5 \mathrm{pmol} / \mathrm{l})$. It remained significantly elevated for 45 $\min (p<0.01)$. Significant concentration changes of calcitonin were not observed after oral administration of either $1000 \mathrm{mg}$ or $2000 \mathrm{mg}$ calcium.

\section{Parathyrin}

A significant decrease of parathyrin secretion occurred immediately after i.v. administration (fig. 5).

Tab. 1. Mean values of urinary calcium concentrations and mean four hour calcium excretion (normal calcium excretion: $<7.5$ $\mathrm{mmol} / 24 \mathrm{~h}$ ) on the control day and after the three different modes of calcium application.

\begin{tabular}{|c|c|c|c|c|c|c|c|c|}
\hline & \multicolumn{4}{|c|}{ Calcium-excretion [mmol/l] } & \multicolumn{4}{|c|}{ Calcium-excretion $[\mathrm{mmol} / 4 \mathrm{~h}]$} \\
\hline & Control & $\begin{array}{l}1000 \mathrm{mg} \\
\text { oral }\end{array}$ & $\begin{array}{l}2000 \mathrm{mg} \\
\text { oral }\end{array}$ & $\begin{array}{l}180 \mathrm{mg} \\
\text { i. v. }\end{array}$ & Control & $\begin{array}{l}1000 \mathrm{mg} \\
\text { oral }\end{array}$ & $\begin{array}{l}2000 \mathrm{mg} \\
\text { oral }\end{array}$ & $\begin{array}{l}180 \mathrm{mg} \\
\text { i. v. }\end{array}$ \\
\hline $0900 \mathrm{~h}$ & $4.44 \pm 2.65$ & $4.86 \pm 3.76$ & $4.93 \pm 2.85$ & $4.53 \pm 1.95$ & - & - & - & - \\
\hline $1300 \mathrm{~h}$ & $4.68 \pm 2.18$ & $6.65 \pm 3.34$ & $6.87 \pm 2.46$ & $8.14 \pm 3.2$ & $1.19 \pm 0.49$ & $2.18 \pm 1.04$ & $2.28 \pm 0.6$ & $2.73 \pm 1.15$ \\
\hline $1700 \mathrm{~h}$ & $3.76 \pm 1.2$ & $5.23 \pm 1.73$ & $5.26 \pm 1.79$ & $5.81 \pm 3.4$ & $0.84 \pm 0.26$ & $1.5 \pm 0.72$ & $1.94 \pm 0.69$ & $1.53 \pm 0.95$ \\
\hline
\end{tabular}




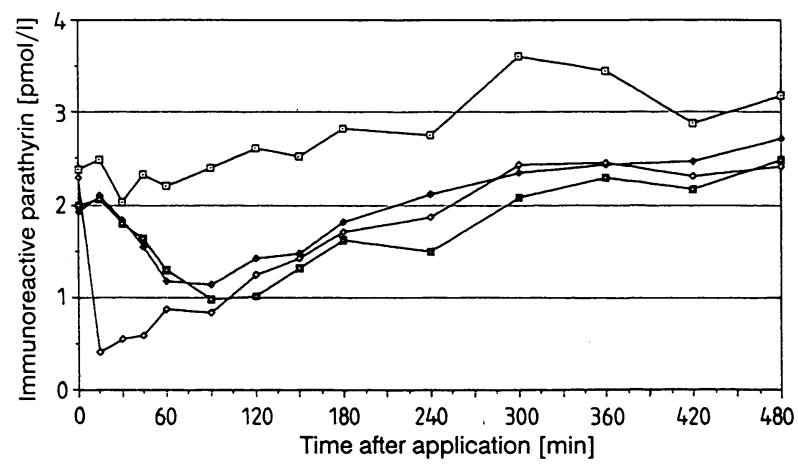

Fig. 5. Parathyroid hormone concentrations on the control day and after the three different modes of calcium application.

Calcium application:

$-\square-\quad$ control

$\longrightarrow \quad 1000 \mathrm{mg}$ oral

$-\square-2000 \mathrm{mg}$ oral

$-\diamond-\quad 180 \mathrm{mg}$ i.v.

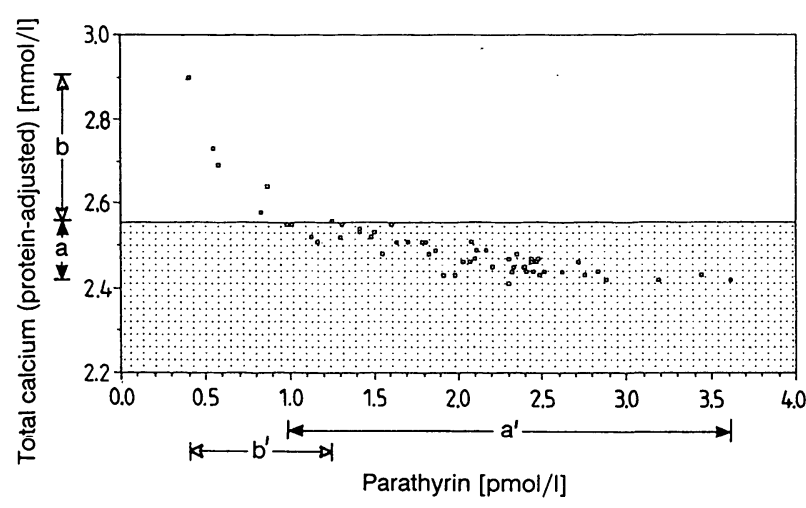

Fig. 6. Mean total calcium concentrations (protein-adjusted) (y-axis) versus mean parathyroid hormone concentrations ( $\mathrm{x}$-axis). The shadowed area indicates the physiological calcium range. One dot refers to the mean data of one sampling time. In the range of 2.41 to $2.55 \mathrm{mmol} / 1$ of serum calcium the parathyroid glands responded to produce a range of intact parthyrin concentrations, in which the highest and lowest values differed by 2.63 $\mathrm{pmol} / \mathrm{l}$ (see a and $\mathrm{a}^{\prime}$ ). Above the physiological calcium range a calcium increase of $0.34 \mathrm{mmol} / 1$ is followed by a parathyrin decrease of only $0.85 \mathrm{pmol} / \mathrm{l}$ (see $\mathrm{b}$ and $\left.b^{\prime}\right)$.

The lowest concentrations were found after $15 \mathrm{~min}$ with a mean decrease of $1.9 \pm 0.88 \mathrm{pmol} / \mathrm{l}(\mathrm{p}<0.01$; range: $(-1.0)-(-3.8) \mathrm{pmol} / \mathrm{l})$. Parathyrin concentrations remained low for $240 \mathrm{~min}(\mathrm{p}<0.05)$.

A statistically significant response of the glands to the oral administration was observed, the lowest parathyrin concentrations occurred at 90 minutes. The mean parathyrin concentration decreased by 0.78 $\pm 0.75 \mathrm{pmol} / \mathrm{l}(\mathrm{p}<0.001$; range: $(-2.2)-(+0.3)$ $\mathrm{pmol} / \mathrm{l})$ after $1000 \mathrm{mg}$ and by $1.02 \pm 0.57 \mathrm{pmol} / \mathrm{l}$ $(\mathrm{p}<0.001$; range: $(-2.0)-(-0.1) \mathrm{pmol} / \mathrm{l})$ after 2000 $\mathrm{mg}$ of calcium. The parathyrin concentrations re- mained significantly lowered for $180 \mathrm{~min}(1000 \mathrm{mg}$; $\mathrm{p}<0.05)$ or $240 \mathrm{~min}(2000 \mathrm{mg} ; \mathrm{p}<0.01)$.

Figure 6 shows the mean total calcium concentrations (protein-adjusted) versus the mean parathyrin values. One dot refers to the mean data of one sampling time. In the range of 2.41 to $2.55 \mathrm{mmol} / \mathrm{l}$ of serum calcium the parathyroid glands responded to produce a range of intact parathyrin concentrations, in which the highest and lowest values differed by $2.63 \mathrm{pmol} / \mathrm{l}$ (see a and $\mathrm{a}^{\prime}$ ). All the calcium concentrations above the normal range were the result of intravenous administration. The parathyroid glands cannot respond to these high calcium concentrations in the same manner as they do in the physiological range: a calcium increase of $0.34 \mathrm{mmol} / 1$ is followed by a parathyrin decrease of only $0.85 \mathrm{pmol} / \mathrm{l}$ (see $b$ and $b^{\prime}$ ).

\section{Phosphate}

The serum phosphate concentrations after calcium administration (i.v. and oral) showed no significant differences in comparison with the control day during the first hours of blood sampling; thereafter, however, the phosphate concentrations rose earlier (fig. 7). The i. v. administration group showed slightly elevated phosphate concentrations after $90 \mathrm{~min}(+0.01 \pm 0.22$ $\mathrm{mmol} / \mathrm{l} ; \mathrm{p}<0.1$; control: $-0.1 \mathrm{mmol} / \mathrm{l})$. A significant difference was observed between $120 \mathrm{~min}$ and $180 \mathrm{~min}$ $(+0.11 \pm 0.25 \mathrm{mmol} / \mathrm{l} ; \mathrm{p}<0.01$; range: $(-0.52)-$ $(+0.42) \mathrm{mmol} / \mathrm{l})$. After oral administration of 2000 mg calcium, significant changes were observed between $120 \mathrm{~min}(\mathrm{p}<0.05)$ and $180 \mathrm{~min}(\mathrm{p}<0.01)$; after $1000 \mathrm{mg}$ calcium, significant changes were observed between $150 \mathrm{~min}(p<0.05)$ and $180 \mathrm{~min}$ $(\mathrm{p}<0.01)$.

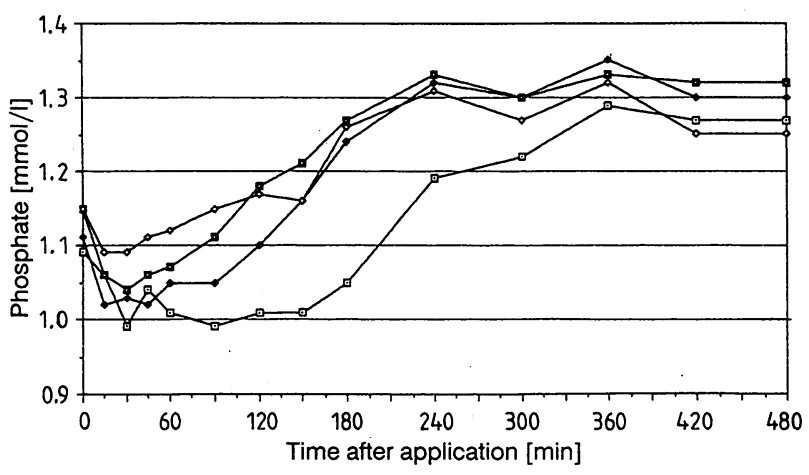

Fig. 7. Phosphate concentration on the control day and after the three different modes of calcium application.

Calcium application:

- - control

$\begin{array}{ll}- & 1000 \mathrm{mg} \text { oral }\end{array}$

$-\diamond-\quad 180 \mathrm{mg}$ i.v. 
Tab. 2. Morning and evening concentrations of calcidiol (25-hydroxycholecalciferol) and calcitriol (1,25-dihydroxycholecalciferol) on the control day and after the three different modes of calcium application.

\begin{tabular}{|c|c|c|c|c|}
\hline \multicolumn{5}{|l|}{ Calcidiol } \\
\hline & Control & $\begin{array}{l}1000 \mathrm{mg} \\
\text { oral }\end{array}$ & $\begin{array}{l}2000 \mathrm{mg} \\
\text { oral }\end{array}$ & $\begin{array}{l}180 \mathrm{mg} \\
\text { i.v. }\end{array}$ \\
\hline $\begin{array}{l}\text { Morning mean } \pm \mathrm{SD} \\
{[\mathrm{nmol} / \mathrm{l}]}\end{array}$ & $61.58 \pm 27.24$ & $58.67 \pm 22.09$ & $61.00 \pm 21.27$ & $60.83 \pm 26.44$ \\
\hline $\begin{array}{l}\text { Evening mean } \pm S D \\
{[\mathrm{nmol} / \mathrm{l})}\end{array}$ & $63.67 \pm 27.93$ & $61.00 \pm 24.31$ & $59.58 \pm 26.03$ & $62.00 \pm 25.11$ \\
\hline \multicolumn{5}{|l|}{ Calcitriol } \\
\hline & Control & $\begin{array}{l}1000 \mathrm{mg} \\
\text { oral }\end{array}$ & $\begin{array}{l}2000 \mathrm{mg} \\
\text { oral }\end{array}$ & $\begin{array}{l}180 \mathrm{mg} \\
\text { i.v. }\end{array}$ \\
\hline $\begin{array}{l}\text { Morning mean } \pm \text { SD } \\
{[\mathrm{pmol} / \mathrm{l}]}\end{array}$ & $109.9 \pm 16.6$ & $95.8 \pm 27.1$ & $106.6 \pm 18.0$ & $100.3 \pm 20.6$ \\
\hline $\begin{array}{l}\text { Evening mean } \pm \mathrm{SD} \\
{[\mathrm{pmol} / 1]}\end{array}$ & $105.1 \pm 19.4$ & $104.1 \pm 20.4$ & $102.5 \pm 22.8$ & $90.5 \pm 17.3$ \\
\hline
\end{tabular}

\section{Calcidiol, calcitriol}

No significant changes in the calcidiol and calcitriol concentrations were observed between the beginning and the end of the different study days. The results are shown in table 2.

\section{Total protein, sodium and potassium}

Total protein, sodium and potassium showed no significant changes during the sampling time, either on the control day or on the study days.

\section{Discussion}

Serum calcium concentrations showed a pronounced initial increase with the risk of hypercalcaemic sideeffects if calcium is given intravenously under the described conditions, while both oral dosages lead to a slow but significant long lasting increase of serum calcium concentration within the physiological range.

Urinary calcium increased substantially after calcium administration, so an increase in fluid intake should be recommended for patients under long-term calcium treatment. The excretion rates after both oral dosages were, however, lower than after intravenous injection. For intravenous injection, a $90 \mathrm{mg}$ ampoule is also available. We selected the $180 \mathrm{mg}$ ampoule, because this is nearer to the suggested amount intestinally absorbed from the tablets.

Despite the higher absorption in the non-fasting state $(4,5)$, the gradual serum calcium increase caused by oral administration was counter-regulated by a slight, though not significant, increase in the calcitonin level and a pronounced decrease in the parathyrin concentration. Due to this sensitive regulation, calcium concentrations almost always remained within the physiological range ( $\leq 2.55 \mathrm{mmol} / \mathrm{l}$ ); only one subject had slightly elevated concentrations in two samples. Oral administration of calcium thus appears to be safe in patients without disturbances of calcium metabolism, i. e. there is no risk of hypercalcaemic side-effects.

There were various effects on the calcium regulating hormones. The morning levels of some variables (e. g. parathyroid hormone) differed slightly between the control day and the other study days. After the 2000 $\mathrm{mg}$ oral dose of calcium, for instance, the parathyrin concentration showed a reduction to $49.2 \%$ of the morning level of the same day but to $38.5 \%$ of the morning level on the control day. This differences is due to the higher morning level of parathyrin on the control day and to the increase of parathyrin during the day. This increase of intact parathyrin in the control group during the day was statistically significant $(\mathrm{p}<0.001)$ (Herfarth et al., in preparation). Despite this, our data of the parathyrin response to oral calcium confirm previous studies on intact parathyrin $(15,21)$. The concentration changes of either calcium or parathyrin after the oral load were twice as rapid in our study as that described by Horowitz et al. in osteoporotic postmenopausal women (17). They observed the peak of serum calcium concentration after a time of three hours in malabsorbers as well as in normal absorbers. It is suggested that this difference might result from age and sex. It might also reflect a disturbed regulation of calcium and bone metabolism in the special situation of osteoporotic 
women. Epstein et al. have described a lower absorption of calcium in the elderly caused by vitamin $D$ deficiency, but not a delay in absorption (2). Further studies should be done to establish the clinical relevance of these phenomena.

A significant change in calcitonin concentration was only observed after i.v. administration but not after the oral calcium loads. This might have been due to the assay sensitivity, but it might also be possible that the thyroidal C-cells only cause a significant change in calcitonin secretion at calcium concentrations above the normal range, and that physiological regulation is effected within very narrow calcitonin concentration limits.

As shown in figure 7, an increase of phosphate occurred within one hour after oral or i.v. administration, but this was statistically significant only after two or more hours. For the study of the phosphate concentrations, comparison with the control period was mandatory as there is a physiological decrease of plasma phosphate from $9 \mathrm{a} . \mathrm{m}$. to noon, followed by an increase. The changes in the phosphate concentrations of the control subjects were similar to the observations of Jubiz et al. (31) who also found that the physiological increase of phosphate is abolished by fasting.

If the differences from the starting concentration of total and ionized serum calcium are plotted, slight decreases are observed on the control day. We suggest that the increase of phosphate during the afternoon is the primary event and that the decrease of calcium and the increase of parathyrin are secondary events, since a primary parathyrin increase should decrease plasma phosphate. Oral or i. v. calcium seems to shift the physiological rhythm of phosphate by advancing it by two to three hours.

An earlier phosphate increase could also be due to the parathyrin decrease after calcium administration. Masked by the physiological increase of phosphate, no return to the baseline of phosphate is visible if parathyrin returns to its former concentration.

\section{References}

1. Sack, H. (1970) Die Calciumresorption. Dtsch. Med. Wochenschr. 95, 398-401.

2. Epstein, S., Van Mieghem, W., Sagel, J. \& Jackson, W. P. U. (1973) Effect of single large doses of oral calcium on serum calcium levels in the young and the elderly. Metabolism 22, 1163-1173.

3. Behne, D., Brätter, P., Herzfeld, U. \& Kraft, D. (1978) Bestimmung der enteralen Resorption hoher Calciumdosen mittels stabiler Isotope. Klin. Wochenschr. 56, 69-74.
No significant changes were observed in the calcidiol and calcitriol values. And no statistically significant difference was observed when the concentration of calcitriol (1,25-dihydroxycholecalciferol) before the start of the study was compared with the final evening value (data not shown).

In summary, in our study, all modes of application of a widely used standard calcium preparation lead to a significant influence on the regulation of calcium metabolism. In contrast to i. v. calcium (injection over 5 minutes), the oral administration was without the risk of hypercalcaemia. A dosage increase from 1000 $\mathrm{mg}$ to $2000 \mathrm{mg}$ yielded no further increase of serum calcium concentrations. Suppression of intact parathyrin for evaluation of patients with suspected hyperparathyroidism may easily be effected by oral ingestion of $1000 \mathrm{mg}$ calcium. Furthermore, a hyperbolic relationship was observed if total serum calcium (y-axis) was plotted versus intact parathyrin (x-axis), and the effect of serum calcium on parathyrin secretion is much larger if calcium is not elevated, but in the normal range. Single intravenous or oral doses have no significant influence on the vitamin D metabolites, calcidiol and calcitriol.

Oral administration of 1000 or $2000 \mathrm{mg}$ calcium yields an increase in serum calcium concentration, which is within physiological limits, but high enough to significantly influence hormonal regulation. A dosage increase is not accompanied by a proportional increase in the hormonal response.

It has to be stressed that our results refer to a single calcium administration in young healthy adults. The effects of long-term calcium therapy on hormonal regulation, especially in elderly people, still have to be established.

\section{Acknowledgement}

The authors thank Dr. Ralf Kohnen, Institute for Medical Research Management and Biometrics, Fürth, Germany, for the statistical evaluation of the data.

4. Griessen, M., Speich, V. P., Infante, F., Bartholdi, P., Cochet, B., Donath, A., Courvoisier, B. \& Bonjour, J.-P. (1989) Effect of absorbable and nonabsorbable sugars on intestinal calcium absorption in humans. Gastroenterology 96, 769-775.

5. Heaney, R. P., Smith, K. T., Becker, R. R. \& Hinders, S. M. (1989) Meal effects on calcium absorption. Am. J. Clin. Nutr. 49, 372-376. 
6. Heaney, R. P., Weaver, C. M. \& Fitzsimmons, M. L. (1990) Influence of calcium load on absorption fraction. J. Bone Min. Res. 5, 1135-1138.

7. Heaney, R. P., Weaver, C. M., Fitzsimmons, M. L. \& Becker, R. R. (1990) Calcium absorptive consistency. J. Bone Min. Res. 5, 1139-1142.

8. Habener, J. F. (1978) Responsiveness of neoplastic and hyperplastic parathyroid tissues to calcium in vitro. J. Clin. Invest. 62, 436-458.

9. Mayer, G. \& Hurst, J. (1978) Sigmoidal relationship between parathyroid hormone secretion rate and plasma calcium concentration in calves. Endocrinology 102, 10361042.

10. Brown, E. M., Brennan, M. F., Broadus, A. E., Marx, S. J., Gardner, D. G., Spiegel, A. M., Downs, R. W., jr., Attie, M. F. \& Aurbach, G. D. (1979) Human parathyroid autografts: comparison of function in vivo and in vitro. $J$. Clin. Endocrinol. Metab. 48, 648-654.

11. Brown, E. M., Gardner, D. G., Brennan, M. F., Marx, S. J., Spiegel, A. M., Attie, M. F., Downs, R. W., Jr., Doppman, J. L. \& Aurbach, G. D. (1979) Calcium-regulated parathyroid hormone release in primary hyperparathyroidism. Am. J. Med. 66, 923-931.

12. Brown, E. M. (1983) Four-parameter model of the sigmoidal relationship between parathyroid hormone release and extracellular calcium concentration in normal and abnormal parathyroid tissue. J. Clin. Endocrinol. Metab. 56, $572-581$.

13. Cantley, L. K., Ontjes, D. A., Cooper, C. W., Thomas, C. G., Leight, G. S. \& Wells, S. A., jr. (1985) Parathyroid hormone secretion from dispersed human hyperparathyroid cells: increased secretion in cells from hyperplastic glands versus adenomas. J. Clin. Endocrinol. Metab. 60, 10321037.

14. D'Amour, P., Labelle, F., Lecavalier, L., Plourde, V. \& Harvey, D. (1986) Influence of serum Ca concentration on molecular forms of PTH in three species. Am. J. Physiol. 251, E680-E687.

15. Hackeng, W. H. L., Lips, P., Netelenbos, J. C. \& Lips, C. J. M. (1986) Clinical implications of estimation of intact parathyroid hormone (PTH) versus total immunoreactive PTH in normal subjects and hyperparathyroid patients. $J$. Clin. Endocrinol. Metab. 63, 447-453.

16. Brent, G. A., LeBoff, M. S., Seely, E. W. \& Brown, E. M. (1987) The influence of the rate of change of serum calcium on the magnitude of the intact parathyroid hormone response in humans. J. Bone Min. Res. 2, 101.

17. Horowitz, M., Morris, H. A., Hartley, T. F., Need, A. G. Wishart, J., Ryan, P. \& Nordin, B. E. C. (1987) The effect of an oral calcium load on plasma ionized calcium and parathyroid hormone concentrations in osteoporotic postmenopausal women. Calcif. Tissue Int. 40, 133-136.

18. Brent, G., LeBoff, M., Seely, E., Conlin, P. \& Brown, E. (1988) Relationship between the concentration and rate of change of calcium and serum intact parathyroid hormone levels in normal humans. J. Clin. Endocrinol. Metab. 67, 944-950.

19. Markowitz, M. E., Arnaud, S., Rosen, J. F., Thorpy, M. \& Laximinarayan, S. (1988) Temporal interrelationships between the circadian rhythms of serum parathyroid hormone and calcium concentrations. J. Clin. Endocrinol. Metab. $67,1068-1073$.
20. Kruse, K., Kracht, U., Wohlfart, K. \& Kruse, U. (1988) Intaktes Serum Parathormon (PTH1-84). Dtsch. Med. Wochenschr. 113, 283-288.

21. Evans, R., Cowper, A., Halkett, J. \& Gunn, I. (1988) Intact molecule PTH: suppression with standard oral calcium load, and analysis of analytical and biological variation in healthy individuals. Ann. Clin. Biochem. 25, Suppl. 176s $177 \mathrm{~s}$.

22. Tohme, J., Bilezikian, J., Clemens, T., Silverberg, S., Shane, E. \& Lindsay, R. (1990) Suppression of parathyroid hormone secretion with oral calcium in normal subjects and patients with primary hyperparathyroidism. J. Clin. Endocrinol. Metab. 70, 951-956.

23. Dawson-Hughes, B., Stern, D., Shioo, C. \& Rasmussen, H. (1988) Effect of lowering dietary calcium on fractional whole body calcium retention. J. Clin. Endocrinol. Metab. 67, 62-68.

24. Blind, E., Schmidt-Gayk, H., Scharla, S., Flentje, D., Fischer, S., Gohring, U. \& Hitzler, W. (1988) Two-site assay of intact parathyroid hormone in the investigation of primary hyperparathyroidism and other disorders of calcium metabolism compared with a midregion assay. J. Clin. Endocrinol. Metab. 67, 353-360.

25. Brasier, A. R., Wang, C. \& Nussbaum, S. R. (1988) Recovery of parathyroid hormone secretion after parathyroid adenectomy. J. Clin. Endocrinol. Metab. 66, 495-500.

26. Husdan, H., Rapaport, A. \& Locke, S. (1973) Influence of posture on the serum concentration of calcium. Metabolism 22, 787-797.

27. Motté, P., Ghillani, P., Troalen, F., Bohuon, C. \& Bellet, D. (1990) Design of new methods for measuring calcitonin and related peptides using monoclonal antipeptide antibodies. In: Calcium regulating hormones, vitamin $D$ metabolites, and cyclic AMP (Schmidt-Gayk, H., Armbruster, F. P. \& Bouillon, R., eds.) pp. 349-364. Springer, Heidelberg-New York.

28. Bouillon, R., Coopmans, W., Degroote, D. E. H., Radoux, D. \& Ellard, P. H. (1990) Immunoradiometric assay of parathyrin with polyclonal and monoclonal region-specific antibodies. Clin. Chem. 36, 271-276.

29. Scharla, S. \& Reichel, H. (1990) A sensitive radioimmunoassay for 1,25-dihydroxyvitamin $\mathrm{D}_{3}$ (calcitriol) after high-performance liquid chromatography of plasma or serum extracts. In: Calcium regulating hormones, vitamin $D$ metabolites, and cyclic AMP (Schmidt-Gayk, H., Armbruster, F. P. \& Bouillon, R, eds.) pp. 300-317. Springer, Heidelberg-New York.

30. Bothe, V. \& Schmidt-Gayk, H. (1990) Competitive proteinbinding assay for the diagnosis of hyper- and hypovitaminosis. In: Calcium regulating hormones, vitamin D metabolites, and cyclic AMP (Schmidt-Gayk, H., Armbruster, F. P. \& Bouillon, R., eds.) pp. 258-279. Springer, Heidelberg-New York.

31. Jubiz, W., Canterbury, J. M., Reiss, E. \& Tyler, F. H. (1972) Circadian rhythm in serum parathyroid hormone concentration in human subjects: correlation with serum calcium, phosphate, albumin, and growth hormone levels. J. Clin. Invest. $51,2040-2046$.

Prof. Dr. med. H. Schmidt-Gayk

Im Breitspiel 15

W-6900 Heidelberg

Bundesrepublik Deutschland 